\title{
BUILDING UP THE STUDETS' ENGLISH VOCABULARY TROUGH FANNY STORIES AT SMP NEGERI 2 DUAMPANUA KAB. PINRANG
}

\author{
Hernawati \\ English Education Department of UIN Alauddin Makassar \\ Hernawati923@gmail.com
}

\begin{abstract}
This research aims to improve the students' English vocabulary through funny stories. The problem statement of the research was "Can Funny Stories Technique Build up the Students' English Vocabulary at SMP Negeri 2 Duampanua?" The objective of the research was to find out whether or not the Funny Stories Technique is able to Build up the Students' English Vocabulary. The researcher applied pre - experimental method with three steps, namely pre - test, treatment and post - test.The population was the students of SMP Negeri 2 Duampanua (academic year 2014 - 2015). There were four classes of the second year students and each class consists of 35 students so the member of population were 140 students. And the sampel technique sampling. It meant that, not all classes of the second year students of SMP Negeri 2 Duampanua Pinrang were taken as sampel, they are 30 students. The instrument of the research used was vocabulary test consist of pretest and posttest design. The descriptive analysis described students' vocabulary achievement with mean score before treatment 30.83 and after treatment 63.16. This research result supported by the inferential statistics by using $\mathrm{t}-$ test. It is used to find out the significant difference between the results of the pre - test and post - test on vocabulary building using Funny Stories Technique. Thus, the value of the $\mathrm{t}-$ test is greater than $\mathrm{t}-$ table $(14.96>2.045)$. It means there is significant difference between the pretest and posttest of the students in vocabulary achievement after presenting the materials by using funny stories.
\end{abstract}

KEY WORDS: Vocabulary, Funny Stories

\section{A. INTRODUCTION}

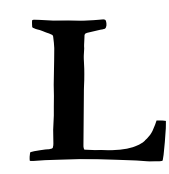

anguage is very important to communicate. People can communicate one another can express their opinion, ideas, feeling, and etc. by using language. There are many languages in the world. One of them is English.

The people have to know about it, because English is international language in the world. We realize that the result of teaching and learning English process is not as 
expected. It can be proved that there are a lot of opinions that English is very difficult subject to study. One of the reasons is the lack of vocabulary. It means that learning language firstly we are learning their vocabulary, as we know vocabulary is one of the language elements play important role.

In addition, Jawariah (2005:03) said that teaching English vocabulary as element of language is considered the most important factor in improving mastery of those skills can be mastered if student are still lacking vocabulary as mentioned that because of lacking of vocabulary, the student cannot grasp someone's ideas that are transmitted to them.Vocabulary as one aspect of language component which is considered playing a control role as a tool of communication and as basic tool of communication in the language learning must be mastered by student because their ability to read and comprehend English writing, speaking, reading and listening

Therefore, the teacher should give strong motivation to the student in learning English as a foreign language, because without it, it would be impossible for the student to be able to learn well. So, the teacher should have good technique or method in teaching and learning process in the classroom. Not only the teacher who always give the student the way for themselves. From the statement above, it is clear that vocabulary is very important for those who want to master English well. There are many factors that the student will master English vocabulary such as the interest or motivation, or the using of some methods in classroom. To teach the student in the classroom the teacher should have a good method, technique and preparation in teaching because the technique and method can help their student to understand more their lesson.

In this research, the researcher would like to introduce a method or technique that teachers can use in teaching vocabulary in the classroom setting. This technique is using funny stories. The teachers will teach the students' English vocabulary through funny stories. This technique is a good for learning and teaching English vocabulary because it will train the students' brain, interest, and challenge. And then, this technique can make the students easy to understand the meaning of the words. In addition, Astuti (2005) in her thesis said that it is very good for the teachers telling funny stories when they teach in the class. It can reduce stress and avoid the students from getting bored, relaxes a stuffy environment because they are all laughing together. Making the learning process more enjoyable can assist in making it more effective and also experience and motivation for them in decision - making in their life. Beside that the students will be able to improve their language skill. They will 
learn new words and practice them in reading stories. They can also improve their skill in good pronunciation.

\section{B. LITERATURE REVIEW}

Vocabulary is one of language elements that are needed in learning and communication. Some writers and researchers have done the research with some various techniques in teaching students' English vocabulary. The results of those research findings are as follows:

Hasan Basri T (2005) conducted a research on the improving the students' vocabulary through reading love stories of Senior High School. He found that one way to present a good condition in teaching English especially English vocabulary in the classroom is by reading love stories. He used in collecting data is vocabulary test, using as pre-test and post-test.

Astuti (2005) in her thesis 'Teaching Vocabulary to the Second Year Students' of SMA 8 Makassar By Using Funny Stories" said that it is very good for the teacher telling funny stories when the teach in the class. It can reduce stress and to avoid the students from getting bored, relaxes a stuffy environment because they are all laughing together. Making the learning process more enjoyable can assist in making in more effective and also experience and motivation for them in decision- making in their life. Beside that the students will be able to improving their language skill. They will learn new words and practice them in reading stories. They can also improve their skill in good pronunciation. Sudarmi (2008) in her thesis said that vocabulary is one of the language elements that play an important role in mastering English, both in oral and written. She used pre-experimental test in her research, using as pre-test and post-test.

\section{Vocabulary}

There are many definitions of vocabulary. According to Oxford Advanced Learner Dictionary of Current English, vocabulary is "total number of words which (with rules for combining them) make up language (rang of) words to or used by, a person in trade, profession etc" (Hornby, 1986).

Vocabulary is a set of words know to a person or other entity, or a part of a particular language. Vocabulary is defined as the set of all words that are understood by the person or all the words which are likely to be used by the person to construct new sentences. 
Vocabulary is the words that people understand both their meaning and usage. Someone must have sufficient vocabulary to understand what is read and heard, to speak and write the right words that could be understood by others.

Instant Vocabulary book, vocabulary is "one of component that is very important in mastering English skill another speaking, reading, writing, and listening. The greater the amount vocabulary that we memorize the faster we dominate an English" (Mahmud Nurdin, 2009).

University Dictionary, vocabulary is "a list of words and sometimes phrase, usually arranged in alphabetical may be categorized as having for separate but largely overlapping components indicate how vocabulary is processed and how it is used. Each of has receptive and productive capacity and within capacity we processed and utilized both spoken and written language" (Webster, 1980).

According to Cambridge International Dictionary of English in Riska Indahyanti's thesis the vocabulary is all the words used by particular person or all the words which exist in particular language or subject. While the New Shorter Oxford English dictionary defines that vocabulary is (1) alphabetical list of words with definitions or translations, as in grammar or reader of foreign language; (2) the range of language of particular author, group, discipline, book, etc; the sum of words known or habitually used by an individual; (3) the sum or aggregate of words composing a language; (4) a set of artistic or stylistic forms, techniques, movements, etc.; the range of such forms available to a particular person.

\section{a. Vocabulary Development}

Harmer in jumriah, (2005:15) defines that vocabulary development can be defined as the action or act of building up vocabulary or word the students' have, or it can also be said that vocabulary development is the elements of English that is being developed. Besides that, in teaching vocabulary the students' must have some elements of English vocabulary, such as noun, conjunction, adverb, adjective, pronoun and interjection. He or she can also develop that students' vocabulary through many ways.

Based on the explanation above, according to the writer words of language is an important element and must be consider as the purpose, so words have a good meaning and form must suitable with formulation well in context.

\section{b. Kinds of Vocabularies}

Page and Thomes (1973) in Mahmud Nurdin (2009) divided vocabulary into two kinds, they are as follows: 
1) Oral vocabulary, consist of words actively used in speech

2) Writing vocabulary is the words.

Harmer (1991: 159) distinguishes two types of vocabulary, namely active and passive vocabulary:

a) Active vocabulary refers to vocabulary that the students have been taught or learnt and which they are expected to be able to use.

b) Passive vocabulary refers to the words which the students will recognize when they meet them but which they will probably not able to produce.

In addition, Sudarmi (2008: 6) divide vocabulary into four types, they are:

a) Active speaking vocabulary, which is words that speaker is able to use in speaking.

b) Passive listening vocabulary, which is words that a listener recognize but can not necessarily produce in speaking.

c) Passive reading vocabulary, which refers to words that a reader recognize but would necessarily, be able to produce.

d) Active writing vocabulary, which is words that a writer is able to use in writing.

In addition, William Schall (1967) classifies vocabulary into three types, they are:

a) Active vocabulary, the word are customarily used in speaking.

b) Reserve vocabulary, the words but we know rarely use in ordinary speech, we use them in writing letters and searching for synonym.

c) Passive vocabulary, the words we recognize vaguely, but we are not sure of the meaning. Never use them in either in speech or writing, we know them because we have them.

\section{c. Type of Vocabulary}

Generally, there are two kinds of vocabulary; they are active and passive vocabulary. The active vocabulary usually the word used in conversation and writing, because they are recognized and understood when read. The passive vocabulary is usually rarely or never used in someone speaking or writing but recognized when met them reading and listening. As Good in Mahmud Nurdin (2009) says that active vocabulary is the function words of a language which are learned, and be able to understand in speaking, reading and writing. While passive vocabulary refers to words which pupils will recognize when they meet them in reading and listening, but the will probably not be able to produce them. 
Similar with Good in Hermer (1991: 159) classifies vocabulary into two types also, namely active and passive vocabulary. To Hermer, active vocabulary refers to words that students have learned and are expected to able to use in communication, while passive vocabulary refers to words that students will recognize when they meet them, although they will probably not able to use them.

According to Neufelds and Guralnik (1995:1494), mentioned types of vocabulary, namely active and passive vocabulary. Where, active vocabulary is all the words recognized and understood by a particular person, although not necessarily used. While passive vocabulary is an interrelated group of nonverbal symbols, signs gestures and so on. It is used for communication or expression in a particular art, skill, etc.

According to Gains and Rendom (1986:64), state that there are two kinds of vocabularies; they are receptive vocabulary and productive vocabulary. Receptive vocabulary refers to language items which we merely known and recognized in the context of reading and listening material. The productive vocabulary is the language items which learner can recall and use in speech and writing appropriately. Then, either receptive or productive vocabulary is often called 'passive' and 'active' vocabulary.

\section{d. Principle of Teaching and Learning Vocabulary}

There are many principles in teaching and learning vocabulary as follows: aims, quantity, need, situation presentation, meaningful presentation, presenting in context, learning vocabulary, inference (guessing) procedure in vocabulary learning, technique in teaching and learning vocabulary.

Wallace in Mulbar (2002) indicates nine principles of teaching and learning vocabulary such as follows:

1) Aims

In the teaching vocabulary, we have to be clear about our aims how to explicitly we must decide the vocabulary that we expect the learner to be able to do. If it is not clear at this point, if will be difficult to assess how success full the vocabulary learning has been.

2) Quantity

Having decided what are involved in vocabulary learning. We may them then decide on the quantity to be taught the number of few students can learn. If we expect the words that will be tough become part of students' active vocabulary, the put number of factors varying from class to class and from learner to learn. 
When there are too many new words, the students may be confused, discouraged and frustrated.

3) Need

The vocabulary that taught the students depend on the course book or syllabus but the teacher should consider the aims of the course and the individual lesson.

4) Situation presentation

The words presented are appropriate to the student's situation.

5) Meaningful presentation

The students must have a clear and specific and understanding of what donates or refers to his required that the presented in such a way the denotation and references are perfectly clear.

6) Presenting in context

The words very seldom occur in isolation, so the students have to know the usual context that the word occurs in.

7) Learning vocabulary and in the mother tongue and in the large language teaching the words of the target language thee teacher can compare simulating and differences of the words

8) Inference (guessing) procedure in vocabulary learning

Inference is also one of strategies in learning in which the learners are heard on a practice by using a definite knowledge to have clear understanding the word they learn. The students infer the meaning of words by listening or reading them used in certain situation.

9) Frequent exposure and Repetition

A certain amount of repetition is necessary until there is a proof that the students have learn the largest word. The simply way of the checking that the students have done the learning is to see whether or not the students can recognize the target words and identify their meanings. If the words have to be part of the students' productive vocabulary, they must be given an opportunity to use them often as necessary for them to the words at all with the correct pronunciation and indentify their meaning.

\section{e. Technique in Teaching and Learning vocabulary}

Similar to Wallace, Allen in Mahbubah (2005) classifies the technique in teaching vocabulary for beginner classes as follows: 
Hernawati, Building Up The Studets' English Vocabulary Trough Fanny Stories ...

1) Let the students look at several words that are introduced in the first year test book, word representing noun, verbs, adjective and others kinds of words. For the young learners are emphasized in simple words such as the animals, fruits etc in noun. Simple verbs that they are usually used in everyday, name of colors, characteristic of person in adjectives and many others that are easy to children comprehending.

2) Showing the real object.

3) Showing some pictures, especially the pictures the students draw.

4) Definition in sample English, using vocabulary that the students know already.

\section{f. Teaching Vocabulary}

The writer will note some opinions dealing with teacher is stated by some expects as follows:

Finnocchiro (1964: 14) states that teacher is the most important element in any teaching situations. It had frequently been said that there are no good and bad methods, but there are good and bad teachers. The personality of teacher completed with attitude toward his pupils, his colleagues, his supervisors, and his attitude work will determine extend to which any program. Naturally the general teaching skill of the instructor, his special training in the field of language learning situation.

Brock I (1986: 140) states that every teacher should find out the most suitable method appropriate to his need. Teachers are free to choose any methods in accordance with their need as long as methods in learning do not falsify and betray objectives the many vary according to ability, it interest, its previous training, the material available, and many others details that the teacher must make the ultimate decision about methods.

Good (1987: 552) points out that teaching 1) narrowly the act of instructing in an educational instruction, instructing 2) Broadly the act of providing activities materials, and guidance that facilitate learning in either formal or non formal.

\section{RESEARCH METHOD}

\section{Desain}

This research used pre-experimental method with one group pre -test and post -test design. The comparison between pre- test and post test score depend on the success of the treatment. The design can be describe as follow:

$$
\text { O1 - X-O2 }
$$


Where:

O1 : Pre test

$\mathrm{X}:$ Treatment

$\mathrm{O} 2$ : Post test

\section{Variables}

There are two variables in this research, namely independent variable and dependent variable. An independent variable is the use of funny stories in teaching vocabulary and dependent variable is the students' achievements after treatment are given.

\section{Research Instrument}

The researcher used a test (pre - test and post - test) as the instrument of collecting data. The test of vocabulary was given to the students through the pre-test and the post-test. The questions were multiple choices. The pre-test was the tests that were given to the students to check their known and unknown of vocabulary. The post-test was the tests that were given to the students to check their vocabulary achievement after learning through Funny Stories.

\section{Population}

The population of the research is the second year students of SMP Negeri 2 Duampanua Pinrang in the academic year 2013 - 2014. There are four classes of the second year students and each class consists of 35 students so the member of population are 140 students.

\section{Sample}

The samples of this research are 30 students. In this case, the researcher will use cluster random sampling.

\section{Procedure of Collecting Data}

The procedures of collecting data are chronologically as follows:

\section{a. Pre test}

The researcher will give the students pre-test to know their achievement in English vocabulary. The students are given a number of questions. Those questions are in multiple choices. 
Hernawati, Building Up The Studets' English Vocabulary Trough Fanny Stories ...

\section{b. Treatment}

After giving the pre-test to the students, the researcher will give the treatment. The researcher will give some materials of vocabulary to the students through funny stories.

\section{c. Post test}

After doing the treatment to the students, the researcher will give the post - test. The researcher will give the same questions as the pre-test to the students. It will aim to know the impact of the implementation of funny stories in building up the students' English vocabulary.

\section{d. Treatment Procedures}

Before giving the students post-test, the researcher gave the students treatment. It conducted in four meetings. In there meetings the writer or the researcher used funny stories in teaching vocabulary. The steps in teaching vocabulary using Funny Stories that described as follows:

1) The researcher introduced the funny stories to the students.

2) The researchers distributed the story to each student and asked the students to read it and to find a new word.

3) The researcher told the story and explained the meaning of the unfamiliar words.

4) Let the class to find out the information and state what funny it.

5) The researcher gave time to the students to repeat that story with their own words.

6) The researcher gave some question correlation with the story for the students.

\section{D.FINDINGS AND DISCASSION}

\section{The Scores, Percentage and Frequency of the Pre - test and Post-test}

It has been mentioned in the previous chapter that after tabulating and analyzing the students' score into percentage, then they were classified into five levels.

The classification of the scores of the students is presented in the Table 1. This table shows that before giving treatment (using funny stories), all the students ability was in very poor classification. After giving treatment, $3(10 \%)$ out of 30 students were in "Very Good" classification, 9 (30\%) of them were in "Good" 
classification, $13(43,3 \%)$ out of the students were in "Fair" classification, and 5 $(16,7 \%)$ out of 30 students were in "Poor" classification. For clear lay out presentation of the data can be seen in the following table:

Table 1

The Scores, Percentage and Frequency of the Pre-test and Post-test

\begin{tabular}{|c|c|c|c|c|c|}
\hline \multirow{2}{*}{ Classification } & \multirow{2}{*}{ Range } & \multicolumn{2}{|c|}{ Pre-Test } & \multicolumn{2}{|c|}{ Post-Test } \\
\hline & & $\mathbf{F}$ & $\%$ & $\mathbf{F}$ & $\%$ \\
\hline Very Good & $90-100$ & 0 & 0 & 3 & 10 \\
\hline Good & $70-89$ & 0 & 0 & 9 & 30 \\
\hline Fair & $50-69$ & 2 & 6.7 & 13 & 43.3 \\
\hline Poor & $30-49$ & 16 & 53.3 & 5 & 16.7 \\
\hline Very Poor & $10-29$ & 12 & 40 & 0 & 0 \\
\hline \multicolumn{2}{|c|}{ Total } & 30 & 100 & 30 & 100 \\
\hline
\end{tabular}

Table 1 above indicates before given treatment, the students' vocabulary was categorized as "Poor", and after given the treatment, the students' vocabulary was categorized "Good". It can be concluded that the rate percentage in the post-test was higher than the percentage in the pre-test. And it means that funny stories technique has a good effect in building up the students' vocabulary.

\section{The Mean Score and Standard Deviation of the Students Pre-test and Post-test.}

After classifying the students' score into five classifications, the researcher calculated the Mean scores and standard deviation as the result of the students pretest and posttest. A pre-test was given before the treatment to know the prior knowledge of the students. While a pot-test conducted after the treatment, which aims to know absorption of the students after giving treatment. Both pre-test and post-test then compared to see whether or not there is significant difference the achievement. The result of the pre-test and post-test were presented in the following data: 
Hernawati, Building Up The Studets' English Vocabulary Trough Fanny Stories ...

Table 2.

The Mean Scores of pre-Test and Post-test and Standard Deviation

\begin{tabular}{|c|c|c|}
\hline Test & Mean Score & Standard Deviation \\
\hline Pre-test & 30.83 & 10.73 \\
\hline Post-test & 63.16 & 16.77 \\
\hline
\end{tabular}

From the table 2 above, the researcher found that Mean score of the students in the pre-test was 30,83. It means that the score of the students in this test was very poor. While the Mean Scores of the students in the post-test was 63,16. It means that the score of the students in this test was good. In the other words, the researcher concludes that teaching vocabulary through funny stories can improve the students' vocabulary.

\section{T- Test value}

To know whether the pre-test and post-test are significantly different, the researcher used t-test. The result of the t-test was 14,96. Then the result of the t-test was compared with the value of $\mathrm{t}$-table. To know the value of $\mathrm{t}$-table, the researcher used the level significance $(p)=0.05$ and found that the degree of freedom ( $\mathrm{df}$ ).

To find out the degree of freedom (df), the researcher used the following formula:

$$
\begin{aligned}
& \mathrm{df}=\mathrm{N}-1 \\
& \mathrm{df}=30-1 \\
& \mathrm{df}=29
\end{aligned}
$$

The following tab/le shows the result of calculation

Table 3

T-test of students' vocabulary achievement

\begin{tabular}{|c|c|c|}
\hline Variable & T-test value & T-table value \\
\hline $\mathrm{X} 2-\mathrm{X} 1$ & 14,96 & 2.045 \\
\hline
\end{tabular}

Table 3 above that t-test value was greater than t-table of the students' achievement. It can be concluded that there is significant difference between the result of the students' pre-test and post-test. 


\section{Hypothesis Testing}

The result of the statically analysis at level of significance $(\mathrm{p})=0,05$ with degrees of freedom $(\mathrm{df})=\mathrm{N}-1$., where $\mathrm{N}=30$ indicate that there was significant difference between the mean score of pre-test and post-test. The mean score of the pre-test was 30,92 and the mean score of the post-test was 63,16 . In addition the ttest value was greater than the t-table value that is $14,96>2.042$. Therefore, the Null hypothesis (Ho) was rejected, while the Alternative hypothesis (Hi) was accepted.

From the analysis above, the researcher concluded that there is a significant difference between pre-test and post-test in the use of funny stories in building up the students' vocabulary. It means that, funny stories are effective to be used in building up the students' vocabulary.

\section{Discussion}

Relating to the data collected through vocabulary test as explained in previous section shows that the students' vocabulary mastery of SMP Negeri 2 Duampanua was good. It was supported by the frequency and the rate percentage of the result of the students' pre-test and post-test. Students' score after presenting materials through funny stories technique in teaching vocabulary was better than before the treatment given to students.

In the pre-test, there were 2 students $(6,7 \%)$ who got 'Fair' score, 16 students $(53,3 \%)$ who got 'Poor' score, 12 students $(40 \%)$ who got 'Very poor' score and none of them who got 'Good' or 'Very good' score. The mean score of the pre-test was 30,83 . And in the post-test, 3 students $(10 \%)$ who got 'Very good' score, 9 students (30\%) who got 'Good' score, 13 students (43,3\%) who got 'Fair' score, 5 students $(16,7 \%)$ who got 'Poor' score and none of them who got 'Very poor' score. The mean score of the post-test was 63,16 . The data shows the result of the rate percentage of the students' pos-test is higher than pre-test before giving treatment.

Based on the result of the t-test value which greater the value of the t-table that is $14,96>2.045$. The researcher found that there was a significant difference between the results of pre-test and post-test. It means that there was significant difference result of the pre-test before and after teaching and learning process through funny stories. This is because the students learned by using an interesting media that could enlarge their knowledge and experience besides that to be familiar with new vocabulary acquisition through funny stories. 
Hernawati, Building Up The Studets' English Vocabulary Trough Fanny Stories ...

From the discussion above, it can be concluded that the second year students of SMP Negeri 2 Duampanua have a good comprehension after learning vocabulary through funny stories technique. In this part, the researcher discusses the result of the students' vocabulary mastery.

\section{E. CONLUSION AND RECOOMENDATION}

\section{Conclusion}

Based on the research findings in the previous chapter, the conclusion can be concluded as follows:

The use of Funny Stories Technique built up the vocabulary of the second year students of SMP Negeri 2 Duampanua which was proved by the result of pretest was 30.83 and post-test was 63.16 .

\section{Recomomendation}

Considering the conclusion above, the researcher further states suggestion as follows:

In teaching vocabulary, the teacher should use some different techniques and ways to attract the students' attention to learn English vocabulary. So it is suggested that the teacher use funny stories in teaching vocabulary as technique to motivate and stimulate the students to learn English. Based on the findings and discussion on the research, the researcher presents suggestion. The students of SMP Duampanua are active in learning vocabulary trough fanny stories, especially in the end of the lesson. So that, fanny stories can be used as one of technique learning vocabulary. Besides that, teacher should be employing some good techniques in teaching vocabulary. The technique use should make the students enjoy the lesson that is interesting and easy to memorize. Above all, the students should have motivation in learning vocabulary.

\section{REFERENCES}

Astuti. Teaching Vocabulary to the Second Year Students' of SMAN 8 Makassar by Using Funny Stories.Thesis FBS UNM, 2005.

Basri T, Hasan. Improving the SMA Students' Vocabulary Mastery through Reading Love Stories.Thesis FBS UNM, 2005. 
Gay, L. R. Educational Research Competencies for Analysis \& Application. New York: Bell \& Howell Company. 2006.

Good, T and J. Brophy. Looking in the Classroom. New York: bHarpe and Row. 1987.

Harmer, Jeremy. The Practice of English Language Teaching. London: Longman Group Uk. Limited. 1991.

Hornby A.S. Oxford Advanced Learner's Dictionary of Current English. Great Britain: Oxford University Press. 1986.

Indahyanti, Riska. The Implementation of Team Game Tournament of Cooperative Learning Method in Improving Students' Vocabulary Acbievement. Thesis FBS UNM. 2010.

Jawariah. Building up Vocabulary Mastery of the Second Year Student of MTS Pesantren An Nabdlah through Translating Test. Thesis UIN Alauddin Makassar. 2005.

Mahbubah, Sitti. The Use of Word Attack in Developing Vocabulary Mastering to the Second Year Students of AliyabBuluLampang DDI MangkosoBarru. Thesis UIN Alauddin. 2005.

Mahmud Nurdin. Improving the English vocabulary of SMAN Negeri 1 Duampanua by using crossword puz?les. Thesis Makassar Muhammadiyah University.2009.

Manser.Oxford Learners Pocket Dictionary. 1991.

Mulbar, Agusman Teaching Vocabulary through Poem to The Second Years Students of SMU Negeri II Makassar. Faculty of Teacher Training and Education. Makassar Muhammadiyah university. 2002.

Ningsih, Prasetya Rahmi. Teaching English Vocabulary of the Fifth Year Students of SD InpersMalengkeri II Through TPR Method. Athesis UNM Makassar. 2008.

Schall, Williams S. Seven Days to Faster Reading. New York: Oxford University Press. Inc. 1967.

Readers Diggest, Selected Articles, Funny Stories, Anecdotes and Humorous Stories.

Sudarmi.. Enriching the Vocabulary of the Second Year Students of SMA Negeri 1 Duampanua through Crossword Puzzles. Thesis FBS UNM. 2008

Sudjada. Metode Stattistik. Bandung; PT. Tarsito. 1982.

Wallace. Teaching Vocabulary ELBS. New York Oxford Universitas. 1989.

Webster. University Dictionary. Massachusetts, USA: A \& C Merriam Company, Publishers. 1980.

Webster's. Encyclopedia Unabridged Dictionary. 1989. 